\title{
NOTICE TO READERS
}

Half life of ${ }^{14} \mathrm{C}$. In accordance with the decision of the Fifth Radiocarbon Dating Conference, Cambridge, 1962, all dates published in this volume (as in previous volumes) are based on the Libby value, $5570 \pm 30 \mathrm{yr}$, for the half life. This decision was reaffirmed at the 9th International Conference on Radiocarbon Dating, Los Angeles/La Jolla, 1976. Because of various uncertainties, when ${ }^{14} \mathrm{C}$ measurements are expressed as dates in years $B P$ the accuracy of the dates is limited, and refinements that take some but not all uncertainties into account may be misleading. The mean of three recent determinations of the half life, $5730 \pm 40 \mathrm{yr}$, (Nature, $\mathrm{v} 195$, no. 4845, p 984, 1962), is regarded as the best value presently available. Published dates in years BP, can be converted to this basis by multiplying them by 1.03 .

AD/BC Dates. In accordance with the decision of the Ninth International Radiocarbon Conference, Los Angeles and San Diego, 1976, the designation of $\mathrm{AD} / \mathrm{BC}$, obtained by subtracting AD 1950 from conventional BP determinations is discontinued in Radiocarbon.

Authors or submitters may include calendar estimates as a comment, and report these estimates as $\mathrm{AD} / \mathrm{BC}$, citing the specific calibration curve used to obtain the estimate. Meaning of $\delta^{14} \mathrm{C}$. In Volume 3, 1961, we endorsed the notation $\Delta$ (Lamont VIII, 1961) for geochemical measurements of ${ }^{14} \mathrm{C}$ activity, corrected for isotopic fractionation in samples and in the NBS oxalic-acid standard. The value of $\delta^{14} \mathrm{C}$ that entered the calculation of $\Delta$ was defined by reference to Lamont VI, 1959, and was corrected for age. This fact has been lost sight of, by editors as well as by authors, and recent papers have used $\delta^{14} \mathrm{C}$ as the observed deviation from the standard. At the New Zealand Radiocarbon Dating Conference it was recommended to use $\delta^{14} \mathrm{C}$ only for age-corrected samples. Without an ane relative to 0.95 NBS oxalic acid. (Proceedings 8th Conference on Radiocarbon Dating, Wellington, New Zealand, 1972). The Ninth International Radiocarbon Conference, Los Angeles and San Diego, 1976, recommended that the reference standard, 0.95 times NBS oxalic acid activity, be normalized to $\delta^{13} \mathrm{C}=-19 \%$.

In several fields, however, age corrections are not possible. $\delta^{14} \mathrm{C}$ and $\Delta$, uncorrected for age, have been used extensively in oceanography, and are an integral part of models and theories. For the present, therefore, we continue the editorial policy of using $\Delta$ notations for samples not corrected for age.

Citations. A number of radiocarbon dates appear in publications without laboratory citation or reference to published date lists. We ask that laboratories remind submitters and users of radiocarbon dates to include proper citation (laboratory number and datelist citation) in all publications in which radiocarbon dates appear.

list citation) in all publications Radiocarbon Measurements: Comprehensive Index, 1950-1965. This index, covering all published ${ }^{14} \mathrm{C}$ measurements revisions made by all laboratories has been

Publication schedule. Beginning with Volume 15, RADIOCARBON has been published in three issues: Winter, Spring, and Summer. Contributors who meet our deadlines will be given priority but publication is not guaranteed in the following issue.

List appears in the third number of each volume. Changes in names or addresses should be reported to the Managing Editor by May 1

列 Starting with Volume 22, RADIOCARBON published a new type of index, organized in chronologic order, according to sample type and by geographic distribution. Authors in chronologic order, according to sample type and by geographic distribution. Authors ume 22 , No. 4,1980 . The editors of RADIOCARBON believe that this practice serves a more useful function. Our readers are encouraged to make further suggestions. 


\section{R A D I O C A R B O N}

Editor: MINZE STUIVer

Managing Editor: RENEE S KRA

Published by

THE AMERICAN JOURNAL OF SCIENCE

Editors: JOHN RODGers, JOHN H OSTROM, ROBERT A BERNER Managing Editor: MARIE C CASEY

Published three times a year, in Winter, Spring, and Summer, at Yale University, New Haven, Connecticut 06511.

Subscription rate $\$ 60.00$ (for institutions), $\$ 40.00$ (for individuals), available only in whole volumes. The Proceedings of the Tenth International Radiocarbon Conference, vol 22, nos. 2 and 3 , are available for $\$ 60.00$. The price of the full volume 22 , nos. $1-4$, is $\$ 60.00$ for individuals and $\$ 80.00$ for institutions.

All correspondence and manuscripts should be addressed to the Managing Editor, RADIOCARBON, Kline Geology Laboratory, Yale University, 210 Whitney Ave, PO Box 6666, New Haven, Connecticut 06511.

INSTRUCTIONS TO CONTRIBUTORS

Manuscripts of radiocarbon papers should follow the recommendations in Suggestions to Authors, 5th ed.* All copy (including the bibliography) must be typewritten in double space. Our deadline schedule is:

$$
\text { For }
$$

Vol 24, No. 1, 1982

Vol 24, No. 2, 1982

Vol 24, No. 3, 1982

Date

Sept. 1, 1981

Jan. 1, 1982

May 1,1982

General or technical articles should follow the recommendations above and the editorial style of the American Journal of Science or the Proceedings of the Tenth International Radiocarbon Conference. Date lists should follow the format shown in the most recent issue of RADIOCARBON. More detailed instructions are available upon request. Separate mailings have been discontinued.

Illustrations should include explanation of symbols used. Copy that cannot be reproduced cannot be accepted; it should be capable of reduction to not more than 10 by 17.5 , all lettering being at least $1 / 16$ inch high after reduction. When necessary, one large map or table can be accepted, if it will not exceed 17.5 inches in width after reduction. Line drawings should be in black India ink on white drawing board, tracing cloth, or coordinate paper printed in blue and should be accompanied by clear ozalids or reduced photographs for use by the reviewers. Photographs should be positive prints. Photostatic and typewritten material cannot be accepted as copy for illustrations. Plates (photographs) and figures (line drawings) should each be numbered consecutively through each article, using arabic numerals. If two photographs form one plate, they are figures A and B of that plate. All measurements should be given in SI (metric units).

Reprints. Thirty separate copies of each article will be furnished to the author free of cost and without previous notice from him; these will be without a cover. The cost of additional copies will, of course, be greater if the article is accompanied by plates involving unusual expense. Copies will be furnished with a printed cover giving the title, author, volume, page, and year, when specially ordered.

Page charges. Each institution sponsoring research reported in a technical paper, not a date list, will be asked to pay a charge of $\$ 50.00$ per printed page, due when galley proof is returned. Institutions or authors paying such charges will be entitled to 100 free reprints without covers (over and above the 30 free reprints furnished the author.) No charge will be made if the author indicates that his institution is unable to pay them, and payment of page charges on an article will not in any case be a condition for its acceptance.

Back issues and price lists may be obtained from the office of RADIOCARBON.

* Suggestions to authors of the reports of the United States Geological Survey, 5th ed, Washington, DC, 1958 (Government Printing Office, \$1.75). 


\section{Radiocarbon}

\section{Proceedings of the 10th}

\section{International Radiocarbon Conference}

Bern/Heidelberg, 19-26 August 1979

Radiocarbon, Volume 22, Numbers 2 \& 3, $1980 @ \$ 60.00$

Please order from: Radiocarbon

Kline Geology Laboratory

Yale University

PO Box 6666

New Haven, CT 06511 


\section{CONTENTS}

Fractionation corrections in radiocarbon dating

$T M L$ Wigley and $A B$ Muller

\section{DATE LISTS}

A Austin Long and $A B$ Muller

Arizona Radiocarbon Dates $\mathbf{X}$

MRRI Thomas D Mathews

Marine Resources Research Institute Radiocarbon Dates III

MRRI Thomas D Mathews and Fonda L Kearns

Marine Resources Research Institute Radiocarbon Dates IV

P Anne Meulengracht, Patrick McGovern, and Barbara Lawn

University of Pennsylvania Radiocarbon

Dates XXI

QU Louis Barrette, Pierre LaSalle, and Claude Samson Quebec Radiocarbon Measurements III

SRR D D Harkness

Scottish Universities Research and Reactor Centre Radiocarbon Measurements IV

USGS Stephen W Robinson and Deborah A Trimble US Geological Survey, Menlo Park, California, Radiocarbon Measurements II

VRI Heinz Felber

Vienna Radium Institute Radiocarbon Dates XI 